\title{
Resistance of thermo-hygro-mechanically densified wood to colonisation and degradation by brown-rot fungi
}

\author{
Francis W.M.R. Schwarze ${ }^{1,2, *}$ and Melanie \\ Spycher ${ }^{1,3}$ \\ ${ }^{1}$ Swiss Federal Laboratories for Material Testing and \\ Research (EMPA), Wood Laboratory, Gallen, \\ Switzerland \\ ${ }^{2}$ Albert-Ludwigs-Universität Freiburg, Freiburg, \\ Germany \\ ${ }^{3}$ EPF Lausanne, Swiss Federal Institute of Technology, \\ Lausanne, Switzerland \\ ${ }^{*}$ Corresponding author. \\ Swiss Federal Laboratories for Material Testing and Research \\ (EMPA), Wood Laboratory, Lerchenfeldstr. 5, 9014 St. Gallen, \\ Switzerland \\ E-mail: francis.schwarze@empa.ch
}

\begin{abstract}
Colonisation and wood degradation by three brown-rot fungi, Coniophora puteana, Gloeophyllum trabeum and Poria placenta, were studied in wood of Norway spruce (Picea abies) subjected to three different treatments: hygro-thermal $(\mathrm{TH})\left(160\right.$ and $\left.180^{\circ} \mathrm{C}\right)$, mechanical densification and thermo-hygro-mechanical (THM) treatment including densification and post-treatment under saturated steam conditions at different temperatures (140, 160 and $180^{\circ} \mathrm{C}$ ). The weight loss induced by all three fungi was lowest in THM-densified wood post-treated at $180^{\circ} \mathrm{C}$. Highest weight losses were recorded for controls and $\mathrm{TH}$-treated wood. Fungal colonisation varied in its intensity, depending on the treatment applied to the wood. Hyphal growth in controls and TH-treated wood was abundant, whereas in densified and THM-densified wood it was sparse and confined predominantly to the cell lumina of earlywood tracheids. Also, penetration of large-diameter hyphae and associated degradation in THM-densified wood was impeded by occlusion of the lumina, associated with irreversible compression (loss in shape memory). In contrast to $C$. puteana and $P$. placenta, which showed typical brown-rot behaviour, $G$. trabeum frequently showed hyphal tunnelling within the secondary walls of tracheids and xylem ray parenchyma of controls and thermally treated wood. Such growth was never observed in THM-densified wood post-treated at $180^{\circ} \mathrm{C}$.
\end{abstract}

Keywords: brown rot; hyphal growth; light microscopy; soft-rot tunnelling basidiomycetes; thermo-hygromechanical (THM) wood; wood densification.

\section{Introduction}

There is a need for cost-effective wood protection methods that do not employ the toxic preservatives used in the past. This need has so far been addressed mainly by the development of various thermal and hydrothermal modification techniques, which reduce the hygroscopicity of wood and increase its resistance to fungal degradation (Boonstra et al. 1998; Tjeersdma et al. 1999, 2000; Militz 2002). Heat treatments can also improve the durability and mechanical properties of wood (e.g., for moulding), and there have been considerable efforts in several countries to develop such techniques (Militz 2002). Some of these treatments involve permanent fixation with steam or a combination of heat and chemicals (Militz 2002).

A process was recently developed for densifying wood by thermo-hygro-mechanical (THM) treatment (Navi and Giradet 2000). The resulting product is several-fold denser than the raw material and shows reduced hygroscopicity, significantly improved mechanical performance and little shape memory (Navi and Giradet 2000). Its resistance to fungal degradation has, however, not been tested.

The purpose of the present study was to test the brown-rot resistance of wood modified by different thermal and densification treatments and to determine whether such resistance is related to patterns of fungal colonisation and cell wall degradation. Wood samples from Norway spruce (Picea abies) were used for this purpose and the brown fungi used in the study were Coniophora puteana, Gloeophyllum trabeum and Poria placenta.

\section{Materials and methods}

\section{Thermo-hygro-mechanical densification}

A total of 60 wood blocks of Picea abies Karst., Norway spruce, (dimensions $150 \mathrm{~mm} \times 25 \mathrm{~mm} \times 15 \mathrm{~mm}$ ) were subjected to the two-stage THM procedure of Navi and Giradet (2000), involving densification and then post-treatment in saturated steam at 140 , 160 and $180^{\circ} \mathrm{C}$. Densification was conducted at $140^{\circ} \mathrm{C}$ in saturated steam for approximately $20 \mathrm{~min}$. The wood samples were compressed under a controlled force (maximum $22 \mathrm{kN}$ ) until they reached a radial compression ratio of $60-70 \%$. The dimensions of the samples after densification were approximately $50 \mathrm{~mm} \times 25 \mathrm{~mm} \times 15 \mathrm{~mm}$. During the subsequent post-treatment, samples were kept under mechanical pressure in saturated steam to eliminate the shape memory. The rate at which this change is effected decreases in proportion to the temperature. The post-treatment time was $180 \mathrm{~min}$ for the samples that had been densified at $140^{\circ} \mathrm{C}$, with periods of 60 and $30 \mathrm{~min}$ used for samples densified at 160 and $180^{\circ} \mathrm{C}$, respectively (Navi and Giradet 2000).

For comparison, 80 wood blocks (20 for each treatment) were either untreated, TH-treated or densified without heat treatment. Hygro-thermal treatment took place in saturated steam at 160 and $180^{\circ} \mathrm{C}$, either for 60 or $30 \mathrm{~min}$. A detailed account of the 
Table 1 Condition and mean density of Norway spruce wood samples before incubation with brown rot fungi $(n=20)$.

\begin{tabular}{|c|c|c|c|c|c|c|c|}
\hline \multicolumn{2}{|c|}{ Condition of Norway spruce wood } & \multicolumn{2}{|c|}{ Temperature $\left({ }^{\circ} \mathrm{C}\right)$} & \multicolumn{2}{|c|}{ Duration (min) } & \multirow{2}{*}{$\begin{array}{l}\text { Set } \\
\text { recovery } \\
(\%)\end{array}$} & \multirow{2}{*}{$\begin{array}{c}r_{0} \\
\left(\mathrm{~g} \mathrm{~cm}^{-3}\right)\end{array}$} \\
\hline & & $\begin{array}{l}\text { Densifi- } \\
\text { cation }\end{array}$ & $\begin{array}{l}\text { Post- } \\
\text { treatment }\end{array}$ & $\begin{array}{l}\text { Densifi- } \\
\text { cation }\end{array}$ & $\begin{array}{l}\text { Post- } \\
\text { treatment }\end{array}$ & & \\
\hline Control & Untreated & - & - & - & - & - & $0.387 \pm(0.02)$ \\
\hline $\mathrm{TH} 160^{\circ} \mathrm{C}$ & $\begin{array}{l}\text { Heat treatment at } \\
160^{\circ} \mathrm{C} \text { under SSC }\end{array}$ & - & 160 & - & 60 & - & $0.406 \pm(0.03)$ \\
\hline $\mathrm{TH} 180^{\circ} \mathrm{C}$ & $\begin{array}{l}\text { Heat treatment at } \\
180^{\circ} \mathrm{C} \text { under SSC }\end{array}$ & - & 180 & - & 30 & - & $0.389 \pm(0.02)$ \\
\hline Densified & $\begin{array}{l}\text { Mechanical densification } \\
\text { under SSC, without } \\
\text { post-treatment }\end{array}$ & 140 & - & 20 & - & 71 & $1.171 \pm(0.01)$ \\
\hline $\operatorname{THM} 140^{\circ} \mathrm{C}$ & $\begin{array}{l}\text { Densification and post- } \\
\text { treatment at } 140^{\circ} \mathrm{C} \\
\text { under SSC }\end{array}$ & 140 & 140 & 20 & 210 & 4.3 & $1.197 \pm(0.01)$ \\
\hline $\mathrm{THM} 160^{\circ} \mathrm{C}$ & $\begin{array}{l}\text { Densification and post- } \\
\text { treatment at } 160^{\circ} \mathrm{C} \\
\text { under SSC }\end{array}$ & 140 & 160 & 20 & 60 & 1.3 & $1.190 \pm(0.01)$ \\
\hline THM $180^{\circ} \mathrm{C}$ & $\begin{array}{l}\text { Densification and post- } \\
\text { treatment at } 180^{\circ} \mathrm{C} \\
\text { under SSC }\end{array}$ & 140 & 180 & 20 & 30 & 0.9 & $1.174 \pm(0.01)$ \\
\hline
\end{tabular}

$r_{0}$, mean density before incubation; SSC, saturated steam conditions.

methods and of the recovery-set for different post-treatments is given by Navi and Giradet (2000).

\section{Inoculation of wood blocks}

The fungi used were as follows:

- Coniophora puteana (Schum.: Fr.) Karst (isolate no. EMPA 62);

- Gloeophyllum trabeum (Pers.: Fr.) Murrill (isolate no. EMPA 100); and

- Poria placenta (Fr.) Cooke (isolate no. EMPA 229)

Identification of pure cultures was confirmed using mycelial character as observed on plates of malt extract agar (MEA) (Stalpers 1978). Test wood blocks, $50 \mathrm{~mm} \times 50 \mathrm{~mm} \times 150 \mathrm{~mm}$, were obtained from the heartwood of living 40-50-year-old trees of Picea abies Karst, and were prepared according to EN 113 (European Committee for Standardisation 1997). The blocks were sterilised with ethylene oxide for approximately $5 \mathrm{~h}$, dried at $100^{\circ} \mathrm{C}$ for $48 \mathrm{~h}$, cooled in a desiccator and then weighed. They were then inoculated and incubated in units with each of the above fungi according to EN 113.

For each treatment/fungus combination and incubation period, 20 wood blocks were set up, together with 20 controls. The units were incubated at a moisture content between $6 \%$ and $10 \%$ in a random array at $22 \pm 1{ }^{\circ} \mathrm{C}$ and $70 \pm 5 \%$ relative humidity for 16 weeks. Before the incubated wood blocks were dried (as above) for measurement of weight loss, they were cleaned and sampled at random points by removing chips of negligible weight. These were plated onto MEA to check whether the decay fungi were the only micro-organisms present, and this was confirmed in all cases.

One-way analysis of variance (ANOVA) of the recorded dry weight losses was performed in Excel with the significance level set at $P<0.05$. A Tukey HSD post hoc test was performed in SPSS to demonstrate differences in means.

\section{Light microscopy}

The incubated test blocks were cut into sub-samples of approx imately $20 \mathrm{~mm} \times 5 \mathrm{~mm} \times 5 \mathrm{~mm}$, with transverse, radial, and tangential faces exposed for examination. These were fixed in $2 \%$ glutaraldehyde buffered at $\mathrm{pH} 7.2-7.4$, dehydrated with acetone and embedded in a methacrylate medium (Schwarze and Fink
1998). They were then sectioned at approximately 2 and $4 \mu \mathrm{m}$ using a rotary microtome (Leica 2040 supercut) fitted with a diamond knife. For general observation of cell wall degradation and hyphal growth, sections were stained for $12 \mathrm{~h}$ in safranin and then counter-stained for $3 \mathrm{~min}$ in methylene blue and for $30 \mathrm{~min}$ in auramin. Early stages of brown rot (observed as loss of birefringence due to cellulolysis) were detected by viewing sections between crossed Nicol prisms (Lohwag 1937; Schulze and Theden 1937; Wilcox 1993). Micrographs were taken on colour film (Kodak ${ }^{13}$ EPY 64T) with a Leitz ${ }^{\oplus}$ Orthoplan microscope fitted with a Leitz-Vario-Orthomat ${ }^{\circledR}$ camera system.

\section{Results and discussion}

\section{Densification resulting from wood treatment}

The treatments resulted in increases in density ranging from three- to four-fold (Table 1). The density of wood blocks exposed to TH-treatment was similar to that of the untreated controls.

THM treatment with post-treatment at $140^{\circ} \mathrm{C}$ compressed the tracheid lumina to a radial width ranging from 1 to $5 \mu \mathrm{m}$ in the latewood and from 1 to $10 \mu \mathrm{m}$ in the earlywood (Figure 1). With post-treatment at $160^{\circ} \mathrm{C}$, the corresponding values were $0.5-2 \mu \mathrm{m}$ in latewood and $1-5 \mu \mathrm{m}$ in earlywood (Figure 1). With post-treatment at $180^{\circ} \mathrm{C}$, most of the latewood tracheid lumina were completely occluded, whereas those of earlywood tracheids were reduced to a width of $0.5-3 \mu \mathrm{m}$ (Figure 1). Such differences were noted by Navi and Giradet (2000), who also showed that "set-recovery" (the tendency for cells to partially re-expand after densification) was reduced by raising the temperature of post-treatment).

\section{Fungal colonisation and wood degradation}

Most test blocks in all the wood treatments were completely colonised by external mycelia after the 16-week incubation period, as assessed by EN 113 criteria (European Committee for Standardisation 1997). 
A

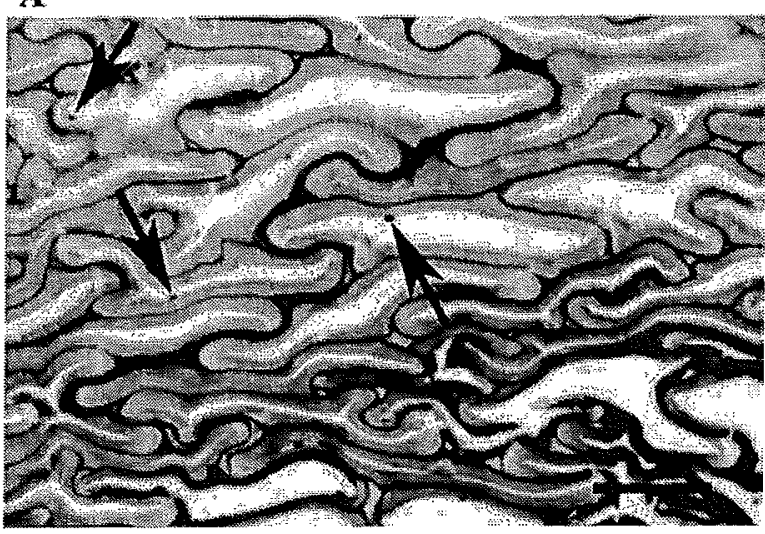

B

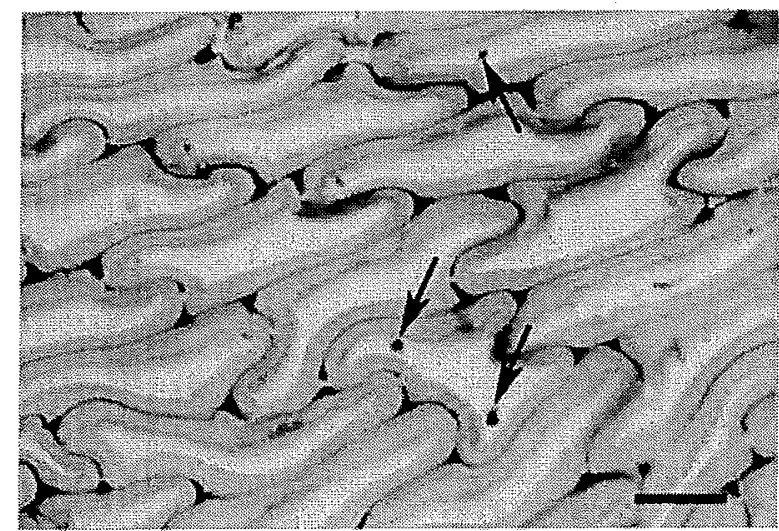

C

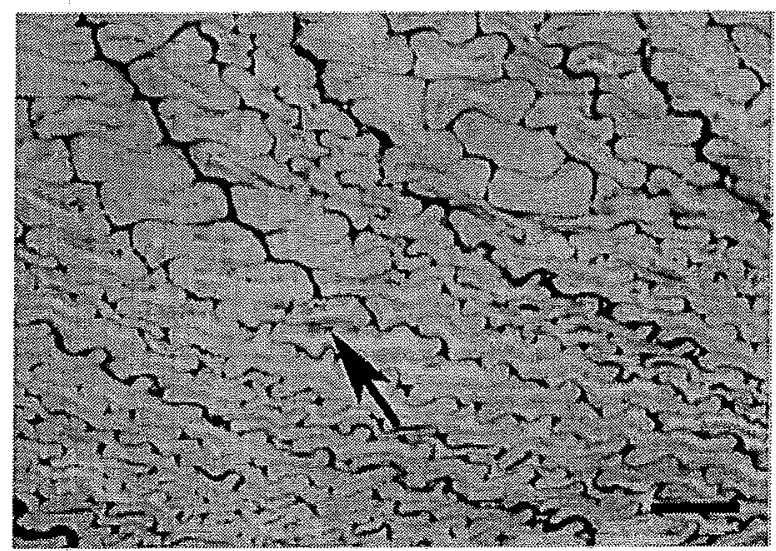

Figure 1 Transverse sections of densified Norway spruce wood; bar represents $10 \mu \mathrm{m}$. (A) Post-treated at $140^{\circ} \mathrm{C}$ and incubated with Poria placenta. Note that the cell lumina of all tracheids are only partially closed. (B) Post-treated at $160^{\circ} \mathrm{C}$ and incubated with Gloeophyllum trabeum. Note that in both (A) and (B) fine hyphae (arrows) are visible within the lumina of earlywood growing on $S_{3}$. Note that in $(B)$ the cell lumina of some tracheids are completely sealed. (C) Post-treated at $180^{\circ} \mathrm{C}$ and incubated with Gloeophyllum trabeum. Note that hyphal growth (arrow) is very sparse and restricted to the earlywood tracheids. The cell lumina of most tracheids are completely sealed.

For each fungus, the weight losses were significantly different $(P<0.05)$ amongst the pre-incubation wood treatments (Figure 2). For all the fungi, the highest weight losses were observed in untreated and TH-treated (160 and $180^{\circ} \mathrm{C}$ ) wood. The lowest weight losses occurred in
THM-densified wood post-treated at $180^{\circ} \mathrm{C}$. Also, the fungi differed in the amount of weight loss that they induced.

Microscopy examination of the wood blocks showed that the differences between treatments regarding weight loss could be partly attributed to the restriction of fungal growth by the occlusion of tracheid lumina. In wood subjected to THM treatment and post-treated at $180^{\circ} \mathrm{C}$, fungal hyphae failed to grow in cell types with completely occluded lumina and were confined to the partially occluded lumina of earlywood tracheids. Comparisons of unoccluded and partially or fully occluded lumina and of the fungal growth within them are illustrated in Figures 1 and 3 for Poria placeta and Figure 4 for G. trabeum. Complete occlusion of all cell lumina would be needed to prevent brown-rot activity, since degradative substances can diffuse from a single hypha in a cell lumen.

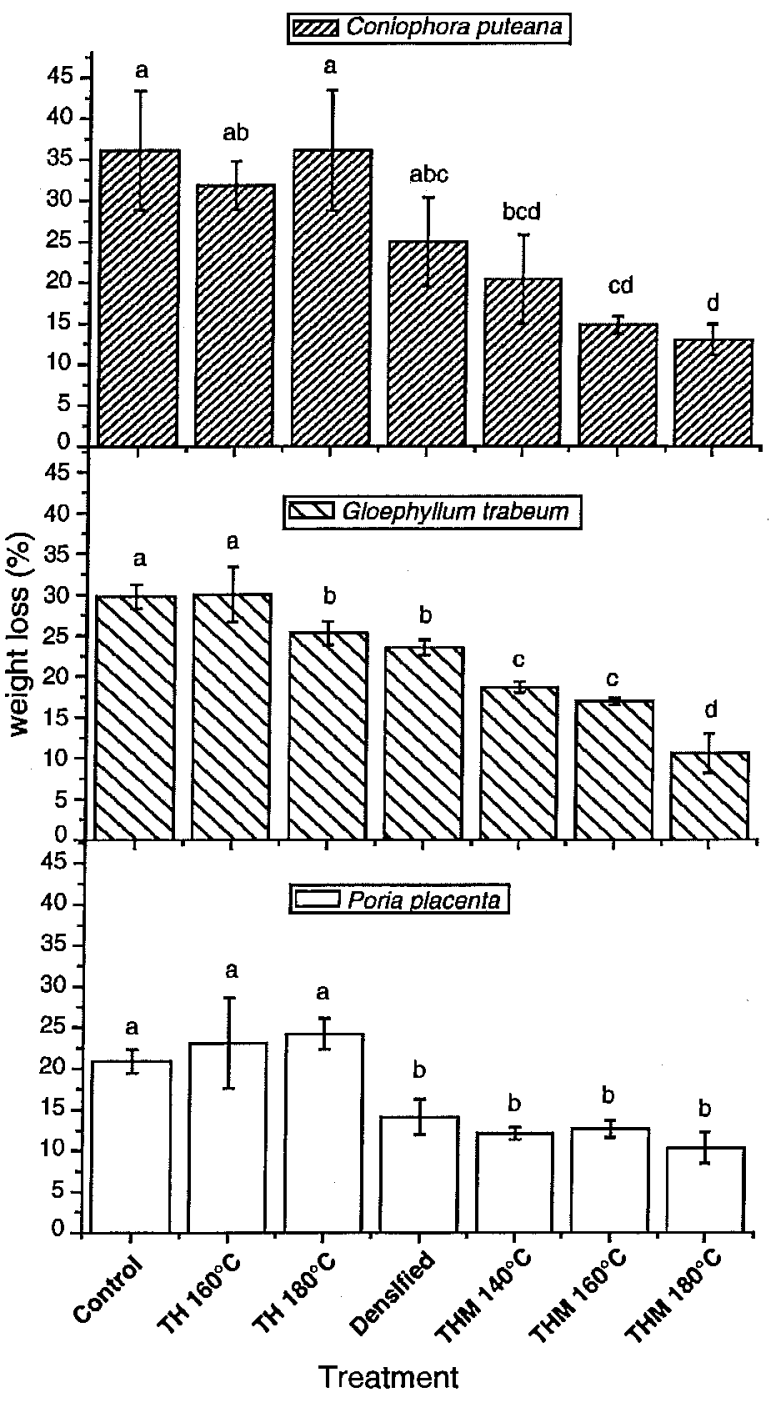

Figure 2 Dry weight losses of wood blocks in untreated controls, $\mathrm{TH}$-treated wood $\left(160\right.$ and $\left.180^{\circ} \mathrm{C}\right)$, densified wood without thermal treatment and THM-densified wood (140, 160 and $180^{\circ} \mathrm{C}$ ) incubated with Coniophora puteana, Gloeophyllum trabeum and Poria placenta $(n=20)$. Bars show standard deviation. Columns sharing the same letters show no significant differences $(P>0.05)$; those not sharing letters show significant differences $(P<0.05)$. 


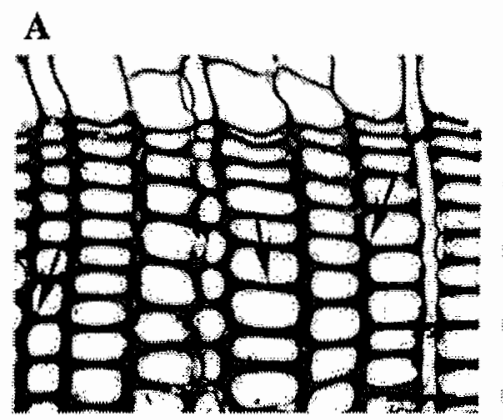

B

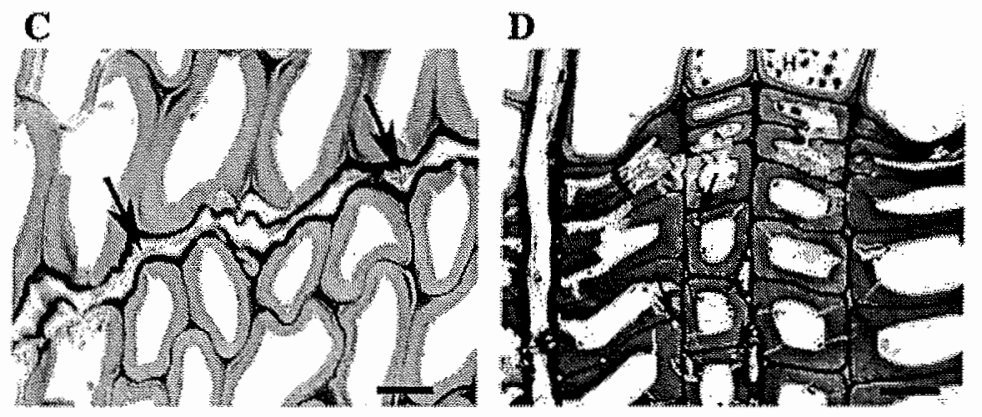

Figure 3 Transverse sections of Norway spruce wood. (A) Untreated wood incubated with Coniophora puteana. Note the fine hyphae (arrows) within the cell lumina of tracheids; bar represents $50 \mu \mathrm{m}$. (B) Untreated spruce wood incubated with Poria placenta. Note the abundant fine large hyphae (arrows); bar represents $50 \mu \mathrm{m}$. (C) Densified wood incubated with Poria placenta. Note that earlywood tracheids are only slightly compressed. Hyphae (arrows) are growing within the cell lumen of xylem ray parenchyma; bar represents $10 \mu \mathrm{m}$. (D) Untreated wood incubated with Gloeophyllum trabeum. Note the formation of boreholes and cavities (arrows) within the secondary walls of tracheids; bar represents $10 \mu \mathrm{m}$.

However, if a high proportion of lumina are completely occluded, this will clearly restrict fungal ingress overall sufficiently to explain why the rate of decay was reduced.

Although fungal hyphae were unable to enter fully occluded lumina and showed restricted development when occlusion was almost complete, the species tested in this study were able to produce narrow hyphae, which may enable them to enter cells with partially occluded lumina. Coniophora puteana produced much narrower hyphae in wood than in agar media and all three fungi showed some effect of substrate (agar versus wood) on their hyphal widths and morphology (Table 2). Poria placenta produced wider hyphae than C. puteana, even in wood, and may therefore be less able to enter partially occluded cell lumina. In wood, the hyphae of $C$. puteana all bore simple clamp connections, whereas those of $P$. placenta were either very fine $(1-2 \mu \mathrm{m})$ and bearing simple clamps, or somewhat wider $(3-9 \mu \mathrm{m})$, with either medallion clamps or simple clamps (Figure 3 ). The hyphae of G. trabeum, which were abundant within the lumina of tracheids and xylem ray parenchyma in undensified wood, possessed numerous clamp connections, sometimes in the form of medallions (Figures 3 and 4).

Hyphal tunnelling through cell walls is another means by which certain fungi may be able to grow through wood in which the lumina are inaccessible (Daniel et al. 1992; Schwarze et al. 1995, 2004; Schwarze and Fink 1997, 1998; Worrall et al. 1997). Only a few brown-rot fungi have been observed to grow in this way (Duncan 1960; Schwarze et al. 2000; Kleist and Schmitt 2001; Kleist et al. 2002) but $G$. trabeum was found to do so in the present study (Figures 3 and 4). It penetrated the secondary walls transversely with very fine hyphae of $<0.5 \mu \mathrm{m}$ in diameter. Tunnelling within the secondary walls began when these hyphae reached the compound middle lamella and changed direction without penetrating it (Figure 4). Enzyme activity along the length of the tunnelling hyphae produced individual cavities of $0.5-2 \mu \mathrm{m}$ in diameter-within the $S_{2}$ layer, following the alignment of the microfibrils (Figures 3 and 4). Longitudinal sections revealed the early stages of cavity formation, which began within the chambers of simple pits, together with localised multiple branching of the hyphae (Figures 3 and 4). Subsequently, individual cavities coalesced to form larger cavities (Figure 4).

Despite the hyphal tunnelling activity of $G$. trabeum, the weight loss caused by this fungus was reduced significantly by THM densification, as in the case of the other two fungi. However, the tunnelling activity was predominantly observed in thermally treated wood, rarely in untreated and densified wood and in THM-densified wood post-treated at 140 and $160^{\circ} \mathrm{C}$. It was never observed in THM densified wood post-treated at $180^{\circ} \mathrm{C}$. The effect of heat treatment is discussed below in relation to the availability of low-molecular-weight carbohydrates and of moisture.

When cell lumen occlusion was absent; (i.e., in untreated wood and in TH-treated non-densified wood), $C$. puteana and $P$. placenta preferentially degraded hemicellulose and cellulose in the tracheid walls, as demonstrated by histochemical staining (red instead of blue; Figure 3). A partial loss of birefringence under polarised light revealed cellulolysis in earlywood tracheids, but not to any significant extent at this stage in the epithelial cells of resin canals and in latewood tracheids. Hyphae were visible within the cell lumina (Figure 3 ) and there was typ- 
Table 2 Hyphal width measured in agar media culture and in wood.

\begin{tabular}{|c|c|c|c|}
\hline \multirow[t]{2}{*}{ Fungal species } & \multicolumn{2}{|c|}{ Hyphal width $(\mu \mathrm{m})$} & \multirow{2}{*}{$\begin{array}{c}\text { Medallion } \\
\text { clamps }\end{array}$} \\
\hline & In agar & In wood & \\
\hline Coniophora puteana & $2.5-8$ & $0.5-2$ & Absent \\
\hline Gloeophyllum trabeum & $1-4.5$ & $1-5$ & Present \\
\hline Poria placenta & $2-8$ & $1-9$ & Present \\
\hline
\end{tabular}

ical cracking of the cell walls extending from the $S_{3}$ layer into the $S_{2}$ and $S_{1}$ layers.

It seems likely that, in addition to causing occlusion of cell lumina, densification reduces the size of voids within cell walls. If so, the diffusion of fungal enzymes through the walls of densified wood may be retarded. A slow rate
A

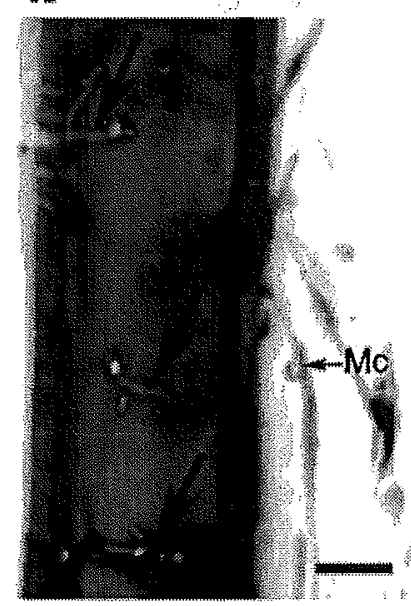

C

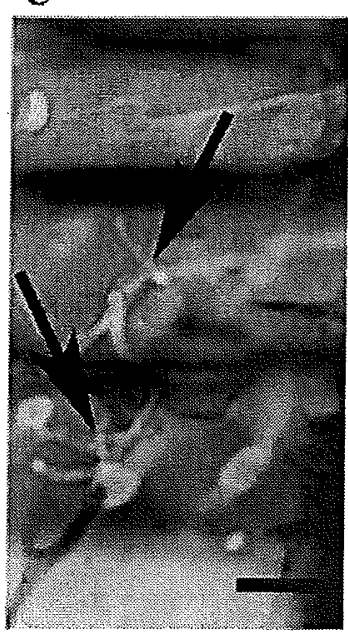

B

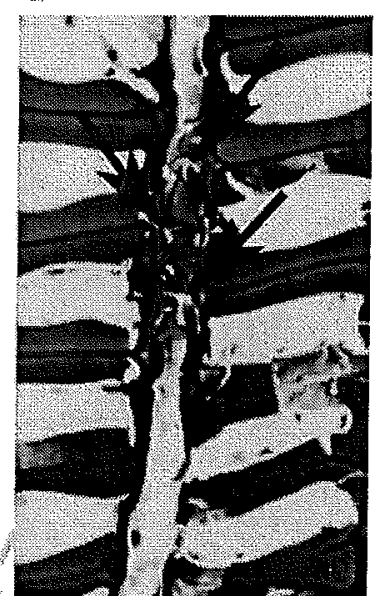

D

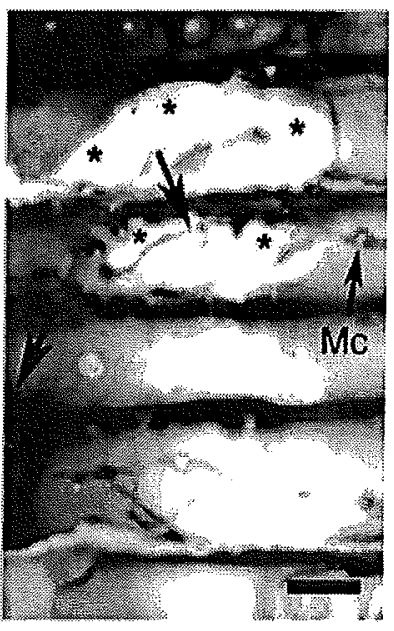

Figure $4 \mathrm{TH}$ treated $\left(160^{\circ} \mathrm{C}\right)$ Norway spruce wood incubated with Gloeophyllum trabeum; bar represents $10 \mu \mathrm{m}$. (A) Radial longitudinal section showing boreholes, multiple hyphal branching (arrows) and cavity formation within the secondary wall of tracheids. Mc, medallion clamp. (B) Transverse section showing hyphal growth (arrows) along the spiral alignment of the cellulose microfibrils. Cavity formation is apparent around the hyphae. (C,D) Radial longitudinal sections showing hyphal growth (arrows) within the secondary walls of xylem ray parenchyma. In regions of the secondary wall where hyphal tunnelling (arrows) has formerly occurred, secondary walls are completely degraded (asterisk). of diffusion may explain why tree species with naturally dense and highly lignified wood are relatively resistant to decay (Rayner and Boddy 1988; Schwarze et al. 2004). This may be particularly important in resistance to brown rot, which mainly involves the diffusion of degradative substances rather than the direct erosion of cell walls by fungal hyphae. Even without densification, pores within undecayed woody cell walls are no more than $2 \mathrm{~nm}$ in diameter (Hill and Papadopoulos 2001) and are therefore too small to allow the diffusion of cellulolytic enzymes (Cowling and Kirk 1976). For this reason, non-enzymatic systems involving substances of low molecular weight have been implicated in the early stages of brown rot, prior to pathways being opened up for the diffusion of enzymes (Koenigs 1974a,b; Murmanis et al. 1987). Evidence for the operation of such systems has, however, been challenged (Kerem et al. 1999).

Apart from the effects of densification on the size of cell lumina and voids within the cell wall, $\mathrm{TH}$ treatment may affect the suitability of wood as a substrate for fungal growth. In the present study, the moisture content of $\mathrm{TH}$-treated wood was found to be far below the fibre saturation point by the end of the 16-week incubation period. Thus, no free water was available within the cell lumina, so that conditions for hyphal growth and wood degradation were unfavourable. These conditions were, however, circumvented by $G$. trabeum, which switched its mode of action to hyphal tunnelling within the secondary wall to utilise the water that was bound there. The relatively rapid degradation of such wood may be also explained by the fact that its density is reduced due to the depolymerisation of polysaccharides; this is estimated to amount to approximately $5-25 \%$ in coniferous wood.

Further studies are currently in progress with the objective of resolving the mechanisms underlying the resistance of THM densified wood post-treated under saturated conditions against brown-, white- and soft-rot fungi.

\section{Conclusions}

Hygro-thermal treatment of wood densified at relatively high temperatures not only increases the dimensional stability, but also seems to make conditions less conducive to hyphal growth within the secondary walls of tracheids and xylem ray parenchyma. The extent to which fungal decay is retarded in this way may be influenced by the hyphal width and colonisation strategies of the fungi concerned.

\section{Acknowledgements}

We appreclate the technical assistance of Markus Heeb and Bruno Zgraggen and that of Mrs. Susanne Röske and Mrs. Karin Waldmann in preparing sections for light microscopy. The authors also wish to thank PD Dr. P. Navi for the preparation of THM wood samples and Dr. D. Lonsdale for comments on the paper. 


\section{References}

Boonstra, M.J., Tjeerdsma, B.F., Groeneveld, H.A.C. (1998) Thermal modification of non-durable wood species. 1. The PLATO technology: thermal modification of wood. International Research Group on Wood Preservation. Document No. IRG/ WP 98-40123.

Gowling, E.B., Kirk, T.K. (1976) Properties of cellulose and lignocellulosic materiais as substrates for enzyme conversion processes. Biotech. Bioeng. Symp. 6:95-124.

Daniel, G., Volc, J., Nilsson, T. (1992) Soft-rot and multiple Tbranching by the basidiomycete Oudemansiella mucida. Mycol. Res. 96:49-54.

Duncan, C.G. (1960) Wood attacking capabilities and physiology of soft-rot fungi. Forest Products Laboratory, US Department of Agriculture, Madison, WI, USA. Report No. 2173.

European Committee for Standardisation. (1997) Standard EN 113. Wood preservatives - test method for determining the protective effectiveness against wood destroying basidiomycetes. Determination of toxic values.

Hill, C.A.S., Papadopoulos, A.N. (2001) A revlew of methods used to determine the size of the cell wall microvoids of wood. J. Inst. Wood Sci. 15:337-345

Kerem, Z., Jensen, K.A., Hammel, K.E. (1999) Biodegradative mechanism of the brown-rot basidiomycete Gloeophyllum trabeum: evidence for an extracellular hydroquinone-driven Fenton reaction. FEBS Lett. 446:49-54.

Kleist, G., Schmitt, U. (2001) Characterisation of a soft-rot-like decay pattern caused by Coniophora puteana (Schum.) Karst. in Sapelli wood (Entandrophragma cylindricum Spague). Holzforschung 55:573-578.

Kleist, G., Ray, M., Murphy, R. (2002) Micromorphology of decay in keruing heartwood by the basidiomycetes Phellinus contiguous and Dacrymyces stillatus. IRG Secreteriat, International Research Group on Wood Preservation. Document No. I IRGNP 02-10454.

Koenigs, J.W. (1974a) Hydrogen peroxide and iron: a proposed system for decomposition of wood by brown-rot basidiomycetes. Wood Fibre 6:66-79.

Koenigs, J.W. (1974b) Production of hydrogen peroxide by wood-rotting fungi in wood and its correlation with weight loss, depolymerization, and $\mathrm{pH}$ changes. Arch. Microbiol. 99:129-145.

Lohwag, K. (1937) Polarisationsmikroskopische Untersuchungen pilzbefallener Hölzer. Mikrochemie 23:198-202.

Militz, H. (2002) Thermal treatment of wood: European processes and their background. IRG Secreteriat, International Research Group on Wood Preservation. Document No. 0240241.
Murmanis, L., Highley, T.L., Hammel, K.E. (1987) Cytochemica localisation of cellulases in decayed and nondecayed wood. Wood Sci. Technol. 21:101-109.

Navi, P. Giradet, F. (2000) Effects of thermo-hydro-mechanical treatment on the structure and properties of wood. Holzforschung 54:287-293.

Rayner, A.D.M., Boddy, L. (1998) Fungal Decomposition of Wood: its Biology and Ecology. John Wiley, Chichester, UK.

Schulze, B., Theden, G. (1937) Polarisationsmikroskopische Untersuchungen über den Werkstoff Holz durch holzzerstörende Pilze. Holz Roh- Werkstoff 1:548-555.

Schwarze, F.W.M.R., Fink, S. (1997) Reaction zone penetration and prolonged persistence of xylem rays in London plane wood degraded by the basidiomycete Inonotus hispidus. Mycol. Res. 101:1201-1214.

Schwarze, F.W.M.R., Fink, S. (1998) Host and cell type affect the mode of degradation by Meripilus giganteus. New Phytol. 139:721-731.

Schwarze, F.W.M.R, Lonsdale, D., Fink, S.(1995) Soft-rot and multiple T-branching by the basidiomycete/nonotus hispidus in ash and London plane. Mycol. Res. 99:813-820.

Schwarze, F.W.M.R., Baum, S., Fink, S. (2000) Dual modes of degradation by Fistulina hepatica in xylem cell walls of Quercus robur. Mycol. Res. 104:846-852.

Schwarze, F.W.M.R, Engels, J., Mattheck, C. (2004) Fungal Strategies of Wood Decay in Trees. $2^{\text {nd }}$ Ed. Springer-Verlag, Heidelberg.

Stalpers, J.A. (1978) Identification of wood inhabiting Aphyllophorales in pure culture. Centraalbureau voor Schimmelcultures, Baarn. Stud. Mycol. 16:1-248.

Tjeersdma, B.F., Boonstra, M., Pizzi, A., Tekely, P., Militz, H. (1999) Characterisation of thermal modifled wood: molecular reasons for wood performance improvement. CP-MAS ${ }^{13} \mathrm{C}$ NMR characterisation of thermal modified wood. Holz RohWerkstoff 56:149-153.

Tjeersdma, B.F., Stevens, M., Militz, H. (2000) Durability aspects of hydrothermal treated wood. IRG Secreteriat, International Research Group on Wood Preservation. Document No. 0040160.

Wilcox, W.W. (1993) Comparative morphology of early stages of brown-rot wood decay. Int. Assoc. Wood Anat. J. 1:127-138.

Worrall, J.J., Anagnost, E., Zabel, R.A. (1997) Comparison of wood decay among diverse lignicolous fungi. Mycologia 89:199-219.

Received September 25, 2004. Accepted January 14, 2005. 